
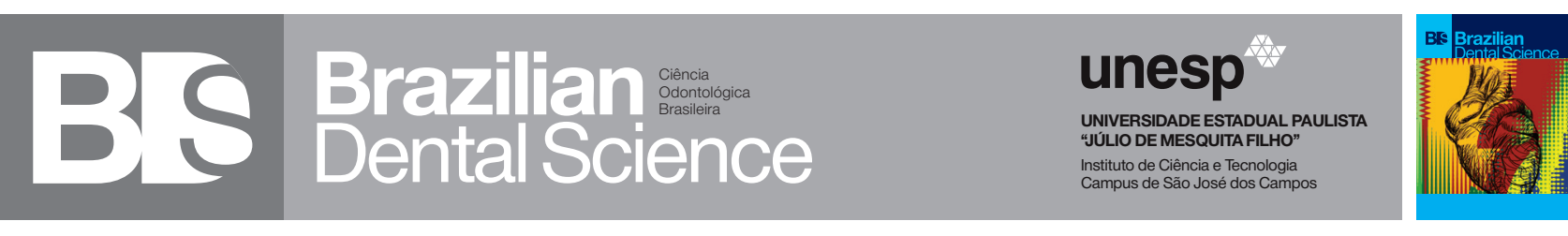

\title{
Effects of intracanal medicaments and the remaining cavity wall on fracture strength of endodontically treated molars
}

Efeitos dos medicamentos intracanais e do muro de cavidade remanescente na força de fratura dos molares endodonticamente tratados

\author{
Keziban OLCAY ${ }^{1}$, Ata Nisa COBAN ${ }^{2}$, Sema BELLI ${ }^{3}$ \\ 1 - Department of Endodontics - Faculty of Dentistry - Istanbul Medipol University - Istanbul - Turkey. \\ 2 - Department of Endodontics - Faculty of Dentistry - Altınbas University- Istanbul - Turkey. \\ 3 - Department of Endodontics - Faculty of Dentistry - Selcuk University - Konya - Turkey.
}

\begin{abstract}
Objective: The aim of this study was to investigate the effects of the short-term intracanal application of two medicaments on the fracture strength of root-filled molar teeth with different levels of tooth structure loss. Material and Methods: Standard access cavities of totally 84 intact maxillary molar teeth were prepared in 72 teeth and were divided into 3 main groups. Standard access cavities were kept in the first group, while mesio-occlusal-distal cavities (MOD) were prepared in the second and third groups. One-half of the palatinal walls were removed in the third group. Twelve sound teeth were used in the fourth group as control. Each group was then assigned into two subgroups according to the medicament used $(n=12): 2 \%$ chlorhexidine gel and calcium hydroxide. Samples were stored at $37^{\circ} \mathrm{C}$ and $100 \%$ humidity for 1 week. Then the teeth were inserted into a universal testing machine and vertically loaded $(5 \mathrm{~mm} / \mathrm{min})$ from the occlusal surface. The data was recorded in Newtons and statistically evaluated using a Univariate ANOVA and a Tukey as post hoc test. Results: A significant difference was found among the test groups $(\mathrm{p}<0.01)$. No significant difference was found according to the medicament used ( $>>0.05)$, however the number of remaining walls significantly affected the fracture strength $(\mathrm{p}<0.01)$. The first group with access cavity showed mostly repairable fractures (60\%-80\%) whereas the others showed mostly nonrepairable fracture patterns (60\%-90\%). Conclusion: In conclusion, the fracture strength of endodontically treated teeth is related to the structure loss rather than the intracanal medicament used.
\end{abstract}

\section{KEYWORDS}

Endodontically treated teeth; Fracture strength; Intracanal medicament; Remaining cavity wall; Root facture.

\section{RESUMO}

Objetivo: O objetivo deste estudo foi investigar os efeitos da aplicação intracanal de curto prazo de dois medicamentos sobre a resistência à fratura de dentes molares preenchidos com raízes com diferentes níveis de perda de estrutura dentária. Material e Métodos: cavidades de acesso padrão de totalmente 84 dentes molar maxilares intactos foram preparadas em 72 , dentes e foram divididas em 3 grupos principais. As cavidades de acesso padrão foram mantidas no primeiro grupo, enquanto as cavidades mesooclusais-distal (MOD) foram preparadas no segundo e terceiro grupos. A metade das paredes palatinas foi removida no terceiro grupo. Doze dentes de som foram utilizados no quarto grupo como controle. Cada grupo foi então atribuído em dois subgrupos de acordo com o medicamento utilizado ( $n=12): 2 \%$ de gel de clorhexidina e hidróxido de cálcio. As amostras foram armazenadas a $37^{\circ} \mathrm{C}$ e $100 \%$ de umidade por 1 semana. Em seguida, os dentes foram inseridos em uma máquina de teste universal e carregados verticalmente ( $5 \mathrm{~mm} / \mathrm{min}$ ) da superfície oclusal. Os dados foram registrados em Newtons e avaliados estatisticamente usando uma ANOVA Univariada e um Tukey como teste post hoc. Resultados: uma diferença significativa foi encontrada entre os grupos de teste $(p<0,01)$. Nenhuma diferença significativa foi encontrada de acordo com o medicamento utilizado ( $p>0,05)$, no entanto, o número de paredes restantes afetou significativamente a resistência à fratura $(\mathrm{p}<0,01)$. $\mathrm{O}$ primeiro grupo com cavidade de acesso apresentou fracturas principalmente reparáveis $(60 \%$ $-80 \%$ ), enquanto as demais apresentaram padrões de fratura não reparáveis (60\% -90\%). Conclusão: Em conclusão, a resistência à fratura dos dentes tratados endodonticamente está relacionada à perda da estrutura em vez do medicamento intracanal utilizado.

\section{PALAVRAS-CHAVE}

Dentes endodonticamente tratados; Força de fratura; Medicamento intracanal; Parede de cavidade restante; Fato de raiz. 


\section{INTRODUCTION}

$\mathrm{T}$ he major aims of root canal treatment are complete debridement of infected tissue and a reduction in the bacterial infection. Calcium hydroxide $(\mathrm{CH})$ has been used for this purpose for decades between the appointments during root canal treatment [1]. CH has many advantages, such as a high $\mathrm{pH}$ [2], antibacterial effects [3], hard tissue stimulation [4], and reduced periapical tissue cytotoxicity [5]. $\mathrm{CH}$ is still a commonly used root canal dressing material for multiple-visit root canal treatments because of its antibacterial activity due to its high $\mathrm{pH}$ level [6].

In addition to the advantages of $\mathrm{CH}$ mentioned above, some studies reported weakening effect of $\mathrm{CH}$ on mechanical properties of tooth structure when used as an intracanal medicament [5,7]. White et al. [8] indicated that root dentin was weakened after 5 weeks of exposure to $\mathrm{CH}$. In a study by Kawamoto et al. [9], $\mathrm{CH}$ exposure caused teeth to be more prone to fracture. Those teeth subjected to a 30day application of $\mathrm{CH}$ were found to require less compressive strength to break in a micro tensile fracture test [1]. In another study [5], it was stated that $\mathrm{CH}$ weakens the dentin at a rate of 23-43.9\%. Andreasen et al. [10] also indicated that the fracture strength of $\mathrm{CH}$-filled immature teeth increased the risk of fracture over the long term. Recently, a few studies supporting the previous results have also been published $[6,11,12]$. Therefore, chlorhexidine (CHX) gel has been suggested as an alternative because of its antimicrobial properties and substantivity $[13,14]$.

To our knowledge, no previous study has compared the effects of using $\mathrm{CH}$ and $\mathrm{CHX}$ gel as intracanal medicaments on the fracture strength of dentin. In addition, no previous study has investigated the effects of the remaining cavity wall on the fracture strength of dentin with intracanal medicaments. Therefore, the goal of this in vitro study was to investigate the effects of the short-term intracanal application of $\mathrm{CH}$ and CHX gel as intracanal medicaments on the fracture strength of molar teeth with different remaining cavity wall levels. The tested null hypotheses were: (i) there will be no difference in the fracture resistance of the dentin when intracanal medicaments $\mathrm{CH}$ and $\mathrm{CHX}$ are used for 1 week, and (ii) root canal treatment with different remaining cavity levels walls will not affect the fracture resistance of maxillary molar dentin.

\section{MATERIALS AND METHODS}

Eighty-four intact, non-carious, extracted human maxillary first and second molars with fully formed roots were selected for this study. The teeth were stored in saline solution for less than three months from the time of extraction and kept moist at room temperature $\left(23 \pm 1 \mathrm{C}^{\circ}\right)$ until they were used for the test. All of the teeth were cleaned with water, and the soft tissue and calculus were debrided mechanically. The teeth were divided into 3 main groups and one control group according to the statistical analysis. The widths of the roots at the cementoenamel junction (CEJ) were measured using a digital caliper (Model CD-6BS; Mitutoyo, Tokyo, Japan) and recorded as $10 \pm 1 \mathrm{~mm}$ buccolingually and $8.6 \pm 1 \mathrm{~mm}$ mesiodistally. A one-way ANOVA was used to analyze the samples. No significant differences in terms of the sample dimensions were found among the groups $(\mathrm{p}=1.000)$.

Twelve teeth were kept as control and standard endodontic access cavities were prepared in 72 teeth with a \#4 round bur (Diatech; Coltène/Whaledent GmbH + Co. KG, Langenau, Germany) under sufficient water cooling, and the root canal patency was achieved using a \#10 K file (Dentsply Maillefer, Ballaigues, Switzerland). To determine the working length, the \#10 K file was placed into the root canal until the end of the file was seen from the apical foramen. The working length was calculated to 
be $0.5 \mathrm{~mm}$ shorter than the apical foramen. All of the root canals were prepared up to AS40 using the Revo-S Classic Rotary System (MicroMega, Besançon, France) in accordance with the manufacturer's instructions. RC-Plus (Medicept, Middlesex, UK) was used for lubrication in the root canal during instrumentation. Irrigation was applied between each file size with $1 \mathrm{ml}$ of $2.5 \%$ sodium hypochlorite $(\mathrm{NaOCl})$ for each root canal. After the preparation was complete, each root canal was finally irrigated with $1 \mathrm{ml}$ of $17 \%$ ethylenediaminetetraacetic acid (EDTA). Then, all of the canals were dried using paper points, and the cavities were prepared as follows:

- Group 1: The standard endodontic access cavities were cleaved as described above by using a diamond fissure burr (Dentsply Maillefer).

- Group 2: In addition to the standard endodontic access cavities, standard MOD cavities were prepared by using a special (extra) shaped diamond bur (\#237/032 EX-26, Dia-Burs; MANI, Inc., Tochigi, Japan). MOD cavities were prepared in the teeth down to the canal orifices so that the thickness of the buccal wall of the teeth measured $2 \mathrm{~mm}$ at the buccal occlusal surface, $2.5 \mathrm{~mm}$ at the CEJ, $1.5 \mathrm{~mm}$ at the lingual occlusal surface and $1.5 \mathrm{~mm}$ at the lingual CEJ.

- Group 3: In addition to the treatment described for group 2, one-half of palatinal walls were additionally removed by using a special (extra) shaped bur (\#237/032, EX-26; MANI, Inc.).

- Control group: Twelve sound, unprepared maxillary molar teeth were used for the controls.

Each of the three experimental groups was randomly divided into two subgroups according to the medicament used $(n=12)$ : CHX gel and
CH subgroups. For the CHX gel subgroup, after the root canal preparation, CHX gel was applied to the root canals using a lentulo spiral. For the $\mathrm{CH}$ subgroup, after the root canal preparation, the canals were filled with a $\mathrm{CH}$ paste that was prepared by mixing $\mathrm{CH}$ powder (Vision Calcium Hydroxide; Anadolu Dis Deposu, Istanbul, Turkey) with normal saline. The access cavities were then sealed with a minimum of $3 \mathrm{~mm}$ thick temporary restorative filling material (Coltosol F; Coltene/Whaledent Inc.) using a spatula. The teeth were stored at $37 \mathrm{C}^{\circ}$ and $100 \%$ humidity for one week.

At the end of the storage period, to simulate the periodontal ligament and alveolar bone support, the root surfaces were dipped into melted wax up to $1 \mathrm{~mm}$ below the CEJ by using a setup for the wax dipping technique (Ceradip; Bego, Germany) to create a $0.2-0.3$ mm thick wax layer. The roots were then vertically embedded in self-curing polymethyl methacrylate resin (Vertex, Dentimex Dental, Zeist, Netherlands) using polyvinyl chlorine molds to a level of 1.0 $\mathrm{mm}$ apical to the CEJ. The resin was mixed according to the manufacturers' instructions and inserted into the molds immediately after mixing. After resin polymerization, the teeth were removed from the resin blocks, and the wax was eliminated using warm water [15]. The space formed between the root surface and the polymethyl methacrylate resin was then filled with silicone paste (Dow Corning 3140 RTV coating; Dow Corning Corp., Midland, MI, USA). The teeth were reinserted into their sockets and any excess impression material was removed with hand instruments. Thus, a standardized simulated periodontal ligament with a thickness of $0.2-0.3 \mathrm{~mm}$ was provided.

After finishing these procedures, the specimens were positioned in a universal testing machine (Instron, Canton, MA, USA) so that the occlusal surfaces of the cores simultaneously came into contact with a 4-mm in diameter steel sphere. All of the specimens were subjected to 
a compressive load at a cross-head speed of 5 $\mathrm{mm} / \mathrm{min}$ until fracture. The force was applied so that it would be parallel to the vertical axis. Each tooth was placed vertically, so that it was placed at the same point each time. The probing was performed to cover the entire occlusal surface at the same time and the teeth were adapted to be equally contacted over all the cuspides. The load that was necessary to fracture each sample was recorded in Newtons $(\mathrm{N})$, and the fracture pattern of each sample was classified as follows:

- Restorable: Core fracture $1 / 2$ above the CEJ and core fracture more than $1 / 2$ above the CEJ or a vertical fracture at the composite core that did not extend into the root.

- Non-restorable: Core fracture (total) above the CEJ and a vertical fracture below the CEJ extending into the root. Vertical longitudinal fractures involving the crown that extended into the root were also considered to be non-restorable.

\section{Statistical analysis}

The statistical analyses of the collected data were performed using SPSS version 17.0 (SPSS Inc., Chicago, IL, USA). The ShapiroWilk's test was used to confirm the assumption of the normality of the data. A Univariate analysis of variance (ANOVA) test was used to determine the differences between the groups, and a post hoc Tukey's test was used to determine the differences between two groups. For all of the tests performed, the level for the significance of the differences was $\mathrm{p} \leq 0.05$.

\section{RESULTS}

The results of the mean fracture strength values and standard deviations of the force required to fracture for the groups are shown in Table 1.

Table 1 - Distribution of fracture strength values according to the test groups

\begin{tabular}{|cccc|} 
& Group1 & Group 2 & Group 3 \\
\hline CHX Subgroup & $1960.3 \pm 653.1$ & $630.7 \pm 237.1$ & $205.4 \pm 70.5$ \\
\hline CH Subgroup & $1388.9 \pm 331.5$ & $673.4 \pm 228.1$ & $398.6 \pm 153.6$ \\
\hline Control Group & & $1634.6 \pm 487.5$ & \\
\hline
\end{tabular}

Mean fracture strength values (in Newton) and standard deviations of the test groups (mean \pm SD).

As a result of the statistical evaluation, no significant difference was found according to the medicament used ( $\mathrm{p}>0.05)$, but the remaining cavity wall significantly affected the fracture strength $(\mathrm{p}<0.01)$.

There was a significant difference between Groups 1 and $2(\mathrm{p}<0.05)$ and Groups 1 and $3(\mathrm{p}<0.05)$, but no significant difference was found between Group 1 and the control group ( $>0.05)$. In addition, there was no significant difference between Groups 2 and 3 ( $p>0.05$ ); however, significant differences were found between Group 2 and the control group $(\mathrm{p}<0.05)$ and Group 3 and the control group $(\mathrm{p}<0.05)$.

The content of medicaments used in the study is summarized in Table 2. 
Table 2 - Chemical composition and application methods of intracanal medicaments

\begin{tabular}{|c|c|c|}
\hline Material & Chemical Composition & Application \\
$\begin{array}{c}\text { Chlorhexidine Gel (Gluco- } \\
\text { CHeX; PPH Cerkamed, Sta- } \\
\text { lowa Wola, Poland) }\end{array}$ & $\begin{array}{c}\text { Chlorhexidine digluco- } \\
\text { nate 2\%, base gel. }\end{array}$ & $\begin{array}{c}\text { Before the treatment immerse the attached applicator into the spirit (ethyl alcohol) and } \\
\text { then place it onto the syringe. Introduce the product into the root canal directly on the } \\
\text { canal instrument or by means of the attached applicator, at the same time prepare the } \\
\text { canal mechanically. While preparing the canal rinse it with hysiological saline or distilled } \\
\text { water. Product intended for multiple use except the applicator which is for single use only. } \\
\text { Multiple use of applicator may cause the risk of reinfection. }\end{array}$ \\
\hline $\begin{array}{c}\text { Calcium Hydroxide (Vision } \\
\text { Calcium Hydroxide; Anadolu } \\
\text { Dis Deposu, Istanbul, Turkey) }\end{array}$ & $\begin{array}{c}\text { Calcium Hydroxide } \\
\text { powder. }\end{array}$ & $\begin{array}{r}\text { Mixed with sterile water, saline or glycerin and applied to the root canal. It is recommended to stay } \\
\text { in the root canal for } 7 \text { to } 14 \text { days for adequate disinfection. }\end{array}$
\end{tabular}

According to the medicament used, there was no significant difference between the $\mathrm{CH}$ and CHX groups ( $\mathrm{p}>0.05)$, however a significant difference was found between the control and the $\mathrm{CH}$ groups $(\mathrm{p}<0.05)$ and the control and the CHX groups $(\mathrm{p}<0.05)$.

The use of the intracanal medication decreased the fracture resistance of Groups 2 and 3 when compared to the control group (intact teeth) with a significant difference $(\mathrm{p}<0.05)$. Reduced fracture resistance was also found in Group 1 when $\mathrm{CH}$ was used as medicament, but the difference was not statistically significant ( $\mathrm{p}>0.05)$.

The distribution of the groups according to the failure patterns is shown in Table 3 . The first group with access cavity showed mostly repairable fracture patterns (60-80\%) (Figure 1 ), whereas the others showed mostly nonrepairable fracture patterns (60-90\%) (Figure 2).

Table 3 - Chemical composition and application methods of intracanal medicaments

\begin{tabular}{|c|ccc|}
\hline \multirow{2}{*}{} & & Repairable (\%) & Non-repairable (\%) \\
\hline \multirow{3}{*}{ CHX } & Group 1 & 60 & 40 \\
& Group 2 & 10 & 90 \\
& Group 3 & 40 & 60 \\
& Group 1 & 80 & 20 \\
\hline \multirow{2}{*}{ CH } & Group 2 & 20 & 80 \\
\hline \multirow{2}{*}{ Control } & Group 3 & 20 & 80 \\
\hline
\end{tabular}

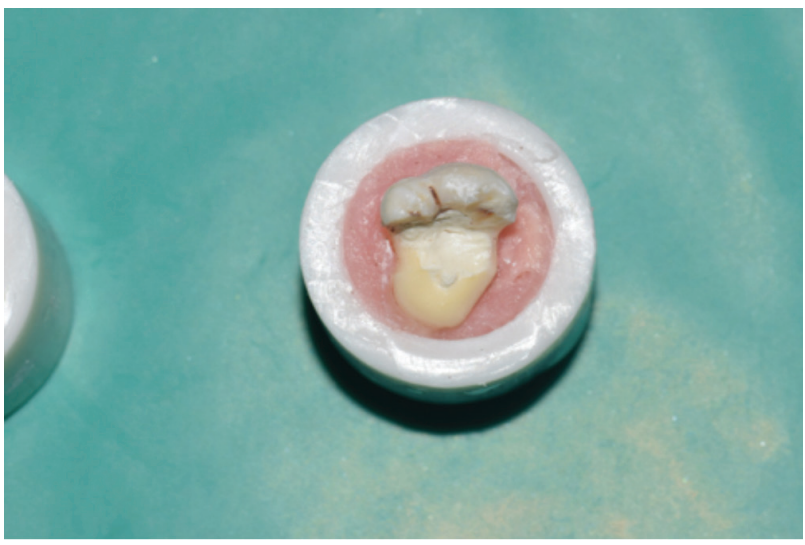

Figure 1 - A photography of a tooth that appears to be a repairable fracture.

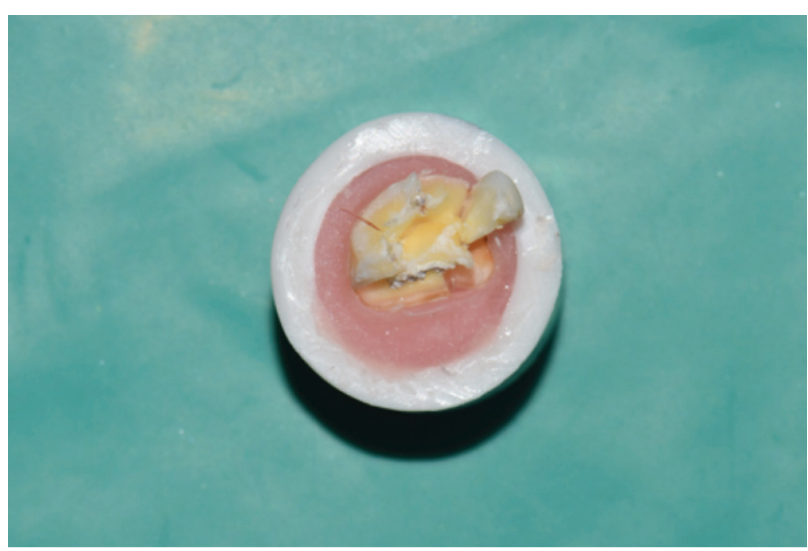

Figure 2 - A photography of a tooth that appears to be a nonrepairable fracture. 


\section{DISCUSSION}

The purpose of this study was to examine the possible destructive effects of $\mathrm{CH}$ and $\mathrm{CHX}$ gel on human root dentin, and the remaining cavity wall levels on the fracture strength of endodontically treated teeth. It is evident from previous studies that the conservation of the tooth structure in the cervical area and a higher number of remaining cavity walls increased the tooth strength $[16,17]$. Higher strength values were expected when the palatinal cavity wall remained. It seems, based on this observation, that the palatinal wall contributed to the fracture resistance and had an increasing effect on the fracture strength values in this study.

$\mathrm{CH}$ has been used in the endodontic treatment of human teeth, often over extended periods of time. In addition, CHX gel is another intracanal medicament that is routinely used in endodontics for reducing microbial growth between sessions. It possesses properties such as substantivity, a broad antibacterial spectrum [18], and a relative absence of cytotoxicity [19]. In order to simulate the clinical conditions, extracted human teeth and a 1 week dressing duration were used in this study.

The fracture strength of the Group 1 with CHX medicament was found to be the highest in this study, while there was no significant difference between the control group and the Group 1 with $\mathrm{CH}$. This finding has not confirmed the well-known fact that tooth structure loss and a long dressing time with $\mathrm{CH}$ significantly reduce the strength of a tooth $[10,20]$. The results of this study have shown that a shortterm root canal dressing with $\mathrm{CH}$ reduced the fracture strength of the dentin, but it was not statistically significant according to the medicament used. The findings of the current study are in accordance with the report by Doyon et al. [21], who demonstrated that a 30-day exposure to $\mathrm{CH}$ had no significant effect on the fracture resistance of dentin disks. Additionally, Moazami et al. [12] reported that the differences between the fracture loads were not significant for $\mathrm{CH}$ in a 7-day period. However, in the same study, the $\mathrm{CH}$ dressings for 30 days and 1 year reduced the flexural strength of the dentin to $72 \%$. One possible explanation for this effect could be the long-term use of $\mathrm{CH}$.

It is evident from previous studies that the root dentin structure is weakened by $\mathrm{CH}$ over time. The Andreasen et al. study [10] showed that the $\mathrm{CH}$ dressing in the root canal had a significantly destructive effect on the fracture strength of the root dentin that was inversely proportional with time. In addition, Rosenberg et al. [5] showed that a $\mathrm{CH}$ root canal dressing reduced the micro tensile fracture strength of teeth by almost 50\% between 7 and 84 days. In another $\mathrm{CH}$ treatment study [6], longterm intracanal dressing with $\mathrm{CH}$ was shown to cause an increase in the fracture risk with regard to the microtensile fracture strength in endodontically treated teeth. White et al. [8] suggested a possible advantage of using a minimal $\mathrm{CH}$ treatment time in the canal to decrease the weakening of the treated teeth. These results are confirmed by the Kawamoto et al. study [9], which showed that exposure to $\mathrm{CH}$ paste significantly increased the mean elastic modulus of bovine dentine from 16.3 to $22.1 \mathrm{GPa}$, with other studies also supporting this [22,23]. As in this study, Grigoratos et al. [14] applied $\mathrm{CH}$ in the root canals for one week; however, they found that the $\mathrm{CH}$ exposure significantly reduced the flexural strength of the root dentin bars. These results can be explained by the differences in the study designs. Sahebi et al. [1] demonstrated that a 30-day root canal dressing with $\mathrm{CH}$ reduced the strength of the dentin of mature human teeth by almost $15 \%$. Moreover, Yassen et al. reported that the 3-month application of $\mathrm{CH}$ paste significantly reduced the fracture resistance of teeth when compared to a 1 week application [24].

One possible explanation for the reducing effect of $\mathrm{CH}$ on the fracture resistance of dentin 
could be its alkaline $\mathrm{pH}$. The protein structure of dentin contributes to the strength of the tooth structure, and a high $\mathrm{pH}$ can cause a breakdown of the protein structure of dentin, therefore weakening the dentin [25]. In addition, the relatively long-term exposure of radicular dentin to $\mathrm{CH}$ might be the reason for the significant reduction in the root's resistance to fracture.

Another possible result of the reduction in the fracture strength may be changes in the organic matrix of the dentin exposed to $\mathrm{CH}$ [10]. A dissolving effect by $\mathrm{CH}$ on the pulp tissue by way of denaturation and hydrolysis has been reported [26], and this may negatively affect the interactions of the collagen fibrils and hydroxyapatite crystals [21]. Moreover, the irrigation protocols suggested during endodontic treatment might cause a further reduction in the root fracture resistance. For example, sodium hypochlorite adversely alters the mechanical properties of root dentin, when used as an endodontic irrigant. In addition, EDTA, which is usually recommended for dissolving inorganic tissue at the end of the endodontic treatment, was found to significantly reduce the root's resistance to fracture [27].

It seems, based on these observations, that the long-term application of $\mathrm{CH}$ to root canal dentin following endodontic treatment could weaken the fracture strength of the dentin. However, in our study, we found that a 1 week intracanal administration, independently of the medicament type used, weakened the root dentin, but the difference found was not significant.

Despite all of these findings, a systematic review of the literature found inconclusive data regarding the negative effects of $\mathrm{CH}$ exposure for 1 month or shorter on the mechanical properties of the radicular dentin [25]. Recently, based on Hawkins et al.'s findings [11], there was insufficient evidence to support $\mathrm{CH}$ causing a decrease in the fracture resistance of dentin over a 6-month period. In the present study, our findings appear not to support the argument that exposure to $\mathrm{CH}$ affects the physical properties of dentin. This may be related to the dentin's shortterm exposure to $\mathrm{CH}$ in our study.

There is limited number of studies in the literature about the effects of CHX on the fracture strength of teeth. In the Valera et al. study [28], irrigation with $2 \% \mathrm{CHX}$ showed a significantly lower fracture resistance than that of the control group. As an intracanal medicament, 0.5\% CHX was added to $\mathrm{CH}$ in Prabhakar et al.'s study [29], and the mixture was applied to the root canal for 30 days. They found no statistically significant changes in the fracture strength values among all of the groups. From these studies, it could be concluded that there is not a full consensus about the effects of CHX on the fracture strength of root canal dentin. Within the limitations of this in vitro study, the results demonstrated that $\mathrm{CH}$ and $\mathrm{CHX}$ dressing for only 7 days did not promote a significant reduction in the dentin fracture resistance. Therefore, a shorter intracanal dressing period is required in root canal therapy to prevent non-restorable fractures in the dentin.

One of the limitations of this study was that the clinical environment of the mouth was not fully tested. The chewing forces, occlusion, and parafunctional habits can also affect the fracture resistance endodontically. Therefore, advanced study designs are needed to clarify the correlation between the intracanal medicaments and the other factors that may cause vertical root fractures. The second limitation of this study could be the short time application of the intracanal medicaments. However, further studies comparing the intracanal medications used in root canal therapy should be designed to better define the most effective period of time for the antimicrobial action, without interfering with the mechanical properties of the weakened roots. 


\section{CONCLUSION}

Within the limitations of this in vitro study, it was concluded that the remaining cavity wall level is more important than the intracanal medicament used for endodontically treated teeth in terms of fracture resistance. Further studies should be performed to confirm these results and evaluate the exact mechanism of dentin fracture resistance.

\section{COMPLIANCE STANDARDS}

\section{WITH}

ETHICAL

\section{Conflict of Interest}

The authors declare that they have no conflicts of interest with regard to this research.

\section{Funding}

This study was performed in the Research Center of Dental Faculty of Selcuk University and supported in part by the Scientific Research Projects Coordination Center of Selcuk University, Konya, Turkey. The authors thank Dr. Serhan Akman for statistical analysis of the study.

\section{Ethical Approval}

All of the procedures performed in this study involving human participants were in accordance with the ethical standards of the institutional and/or national research committee and with the 1964 Helsinki Declaration and its later amendments or comparable ethical standards.

\section{REFERENCES}

1. Sahebi S, Moazami F, AbbottP. The effects of short-term calcium hydroxide application on the strength of dentine. Dent Traumatol. 2010 Feb;26(1):43-6.

2. Zmener 0,Pameijer $\mathrm{CH}$, Banegas $\mathrm{G}$. An in vitro study of the $\mathrm{pH}$ of three calcium hydroxide dressing materials. Dent Traumatol. 2007 Feb;23(1):21-5.

3. Lima RK, Guerreiro-Tanomaru JM, Faria-Júnior NB, Tanomaru-Filho M. Effectiveness of calcium hydroxide-based intracanal medicaments against Enterococcus faecalis. Int Endod J. 2012 Apr;45(4):311-6.
4. Holland R, de Souza V. Ability of a new calcium hydroxide root canal filling material to induce hard tissue formation. J Endod. 1985 Dec;11(12):535-43.

5. Rosenberg B, Murray PE, Namerow K. The effect of calcium hydroxide root filling on dentin fracture strength. Dent Traumatol. 2007 Feb;23(1):26-9.

6. Batur YB, Erdemir U, Sancakli HS. The long-term effect of calcium hydroxide application on dentin fracture strength of endodontically treated teeth. Dent Traumatol. 2013 Dec;29(6):461-4.

7. Doyon GE, Dumsha T, von Fraunhofer JA. Fracture resistance of human root dentin exposed to intracanal calcium hydroxide. J Endod. 2005 Dec;31(12):895-7.

8. White JD, Lacefield WR, Chavers LS, Eleazer PD. The effect of three commonly used endodontic materials on the strength and hardness of root dentin. JEndod. 2002 Dec;28(12):828-30.

9. Kawamoto R, Kurokawa H, Takubo C, Shimamura Y, Yoshida T, Miyazaki M. Change in elastic modulus of bovine dentine with exposure to a calcium hydroxide paste. J Dent. 2008 Nov;36(11):959-64.

10. Andreasen J0, Farik B, Munksgaard EC. Long-term calcium hydroxide as a root canal dressing may increase risk of root fracture. Dent Traumatol. 2002 Jun;18(3):134-7.

11. Hawkins JJ, Torabinejad M, Li Y, Retamozo. Effect of three calcium hydroxide formulations on fracture resistance of dentin over time. Dent Traumatol. 2015 0ct;31(5):380-4.

12. Moazami F, Sahebi S, Jamshidi D, Alavi A. The long-term effect of calcium hydroxide, calcium-enriched mixture cement and mineral trioxide aggregate on dentin strength. Iran Endod J. 2014 Summer;9(3):185-9.

13. Carrilho MR, Carvalho RM, Sousa EN, Nicolau J, Breschi L, Mazzoni A, et al. Substantivity of chlorhexidine to human dentin. Dent Mater.2010 Aug;26(8):779-85.

14. Grigoratos D, Knowles J, Ng YL, Gulabivala K. Effect of exposing dentine to sodium hypochlorite and calcium hydroxide on its flexural strength and elastic modulus. Int Endod J. 2001 Mar;34(2):113-9.

15. Soares CJ, Pizi EC, Fonseca RB, Martins LR. Influence of root embedment material and periodontal ligament simulation on fracture resistance tests. Braz Oral Res. 2005 Jan-Mar;19(1):11-6.

16. Belli S, Celik K, Akbulut MB, Guneser MB, Eraslan 0, Eskitascioglu G. Are dentin posts biomechanically intensive? A laboratory and FEA study. J Adhes Sci Technol. 2014:28:2365-77.

17. Sorrentino R, Monticelli F, Goracci C, Zarone F, Tay FR, García-Godoy F, et al. Effect of post-retained composite restorations and amount of coronal residual structure on the fracture resistance of endodontically-treated teeth. Am J Dent. 2007 Aug;20(4):269-74.

18. Vaghela DJ, Kandaswamy D, Venkateshbabu N, Jamini N, Ganesh A Disinfection of dentinal tubules with two different formulations of calcium hydroxide as compared to $2 \%$ chlorhexidine: As intracanal medicaments against Enterococcus faecalis and Candida albicans: An in vitro study. J Conserv Dent. 2011 Apr;14(2):182-6.

19. Jeansonne MJ, White RR. A comparison of $2.0 \%$ chlorhexidine gluconate and $5.25 \%$ sodium hypochlorite as antimicrobial endodontic irrigants. J Endod. 1994 Jun;20(6):276-8.

20. Celik K, Belli S. The Effect of different restoration techniques on fracture strength of teeth with flared roots. J Adhes Sci Technol. 2015;29:12-23.

21. Doyon GE, Dumsha T, von Fraunhofer JA. Fracture resistance of human root dentin exposed to intracanal calcium hydroxide. J Endod. 2005 Dec;31(12):895-7. 
22. Hatibović-Kofman S, Raimundo L, Zheng L, Chong L, Friedman M Andreasen JO. Fracture resistance and histological findings of immature teeth treated with mineral trioxide aggregate. Dent Traumatol. 2008 Jun;24(3):272-6.

23. Sahebi S, Nabavizadeh M, Dolatkhah V, Jamshidi D. Short term effect of calcium hydroxide, mineral trioxide aggregate and calcium-enriched mixture cement on the strength of bovine root dentin. Iran Endod J. 2012 Spring;7(2):68-73.

24. Yassen GH, Vail MM, Chu TG, et al. The effect of medicaments used in endodontic regeneration on root fracture and microhardness of radicular dentine. Int Endod J. 2013 Jul;46(7):688-95.

25. Yassen GH, Platt JA. The effect of nonsetting calcium hydroxide on root fracture and mechanical properties of radicular dentine: a systematic review. IntEndod J. 2013 Feb;46(2):112-8. doi: 10.1111/j.1365-2591.2012.02121.x. Epub 2012 Sep 13.
26. Andersen M, Lund A, Andreasen JO, Andreasen FM. In vitro solubility of human pulp tissue in calcium hydroxide and sodium hypochlorite. Endod Dent Traumatol. 1992 Jun;8(3):104-8.

27. Uzunoglu E, Aktemur S, Uyanik MO, Durmaz V, Nagas E. Effect of ethylenediaminetetraacetic acid on root fracture with respect to concentration at different time exposures. J Endod. 2012 Aug;38(8):1110-3 .

28. Valera MC, Albuquerque MT, Yamasaki MC, Vassallo FN, da Silva DA, Nagata JY. Fracture resistance of weakened bovine teeth after long-term use of calcium hydroxide. Dent Traumatol. 2015 0ct;31(5):385-9.

29. Prabhakar AR, Hadakar SG, Raju OS. Comparative evaluation of pH and antibacterial effect of various calcium hydroxide combinations on $\mathrm{E}$. faecalis and its effect on root strength: An in vitro study. Contemp Clin Dent. 2012 Jan;3(1):42

\section{Keziban Olcay}

\section{(Corresponding address)}

Atatürk Bulvarı, No:27, Department of Endodontics, Faculty of Dentistry, Istanbul Medipol University, Unkapanı, Fatih, Istanbul.

E-mail: kolcay@medipol.edu.tr

Phone: +90 212453 4800-4958

Date submitted: 2017 Nov 03

Fax: +90 3322230062 